\title{
Analisis Curah Hujan Serial Terhadap Debit Maksimum di Sub DAS Lesti, DAS Brantas, Provinsi Jawa Timur
}

\section{Aaron Jeremy Februanto ${ }^{1 *}$, Lily Montarcih Limantara ${ }^{1}$, Jadfan Sidqi Fidari ${ }^{1}$}

${ }^{1}$ Jurusan Teknik Pengairan, Fakultas Teknik, Universitas Brawijaya, Jalan MT. Haryono No. 167, Malang, 65145, INDONESIA

*Korespondensi Email: aaronjeremyfeb@gmail.com

\begin{abstract}
Changes in climate and land use cause a high potential for flooding in the Lesti watershed. Rainfall that can cause flood discharge varies greatly, so an analysis of the equality of rainfall with discharge is needed. In this study, we will discuss the comparative analysis of serial rainfall with design rainfall to determine the amount of serial rainfall that can cause flooding. The method used in this research is Nakayasu Synthetic Hydrograph Unit and Collins Observation Unit Hydrograph so that the results are equivalent to rain which can cause flooding. Serial rainfall with a height of $58 \mathrm{~mm}$ will be equivalent to a design rainfall of $87.37 \mathrm{~mm}$ with a return period of 2 years. The peak discharge value and peak time between Collins and Nakayasu have deviation results with a relative error for the peak time of $9.173 \%$, while for peak discharge of 9.999\%. The AWLR discharge of $187.29 \mathrm{~m}^{3} / \mathrm{s}$ on 5 April 2015 will be equivalent to the design flood discharge with a 2-year return period of $189,143 \mathrm{~m}^{3} / \mathrm{s}$.
\end{abstract}

Keywords: HSO Collins, HSS Nakayasu, maximum discharge, serial rainfall.

Abstrak: Perubahan iklim dan tata guna lahan menyebabkan potensi bencana banjir yang tinggi pada DAS Lesti. Curah hujan yang dapat menyebabkan terjadinya debit banjir sangat bervariasi, sehingga dibutuhkan adanya analisis kesetaraan curah hujan dengan debit. Pada penelitian ini akan dibahas mengenai analisa perbandingan curah hujan serial dengan curah hujan rancangan untuk mengetahui besaran curah hujan serial yang dapat menyebabkan banjir. Metode yang digunakan dalam penelitian ini adalah Hidrograf Satuan Sintetis Nakayasu dan Hidrograf Satuan Observasi Collins sehingga didapatkan hasil kesetaraan hujan yang dapat mengakibatkan banjir. Curah hujan serial dengan tinggi sebesar 58 $\mathrm{mm}$ akan setara dengan curah hujan rancangan sebesar 87,37 $\mathrm{mm}$ dengan kala ulang sebesar 2 tahun. Nilai debit puncak dan waktu puncak antara 
Collins dan Nakayasu memiliki hasil penyimpangan dengan kesalahan relatif untuk waktu puncak sebesar $9,173 \%$, sedangkan untuk debit puncak sebesar 9,999\%. Debit AWLR sebesar 187,29 $\mathrm{m}^{3} / \mathrm{dt}$ pada tanggal 5 April 2015 akan setara dengan debit banjir rancangan dengan kala ulang 2 tahun sebesar $189.143 \mathrm{~m}^{3} / \mathrm{dt}$.

Kata kunci: curah hujan serial, debit maksimum, HSO Collins, HSS Nakayasu.

\section{Pendahuluan}

Pembangunan infrastruktur sumber daya air memerlukan analisa hidrologi sebagai dasar perencanaan. Informasi hidrologi sangat dibutuhkan untuk digunakan dalam analisis ketersediaan air maupun analisis banjir rancangan[1]. Jika informasi yang ada tidak akurat maka dapat menyebabkan kesalahan analisis. Oleh karena itu untuk menghasilkan nilai analisis banjir rancangan yang sesuai, dibutuhkan data kejadian banjir yang sesuai dengan fakta lapangan. Untuk menganalisis prakiraan debit harian, diperlukan data yang paling tepat, yang sangat diperlukan dalam penelitian ini. Data yang dimaksud adalah data historis dari catatan hujan harian dan catatan aliran harian yang tercatat dalam Automatic Water Level Recorder (AWLR) di lokasi selama periode waktu yang sama, kemudian data ini digunakan untuk simulasi model prediksi aliran harian DAS Lesti.

Perencanaan bangunan-bangunan air yang ada di DAS Lesti memerlukan data air tinggi dan data air rendah yang digunakan untuk memperkirakan fungsi dan keamanan dari bangunan pada DAS Lesti. Data-data air rendah digunakan untuk merencanakan fungsi layanan dari bangunan air yang akan dibangun meliputi debit andalan, debit minimum dan debit rata-rata[2]. Untuk merencanakan keamanan dari bangunan air, maka diperlukan desain debit banjir dan desain debit puncak (PMF) sehingga dapat dihitung dan direncanakan gaya-gaya maksimum yang mungkin terjadi terhadap keamanan bangunan tersebut.

Curah hujan yang dapat menyebabkan terjadinya debit banjir sangat bervariasi, sehingga dibutuhkan adanya analisis kesetaraan curah hujan dengan debit. Pada penelitian ini akan dibahas mengenai analisa perbandingan curah hujan serial dengan curah hujan rancangan. Selain itu juga untuk mengetahui besaran debit rancangan yang ada di DAS Lesti. Data curah hujan yang digunakan, akan mempengaruhi hasil dari debit maksimum pada DAS Lesti. Sedangkan untuk menganalisis debit puncak, akan membutuhkan data curah hujan dan data kejadian banjir atau single peak yang terukur pada stasiun hujan otomatis dan debit yang terukur pada stasiun AWLR.

\section{Bahan dan Metode}

\subsection{Bahan}

Secara administratif daerah studi adalah terletak di Kabupaten Malang, Provinsi Jawa Timur. Lokasi studi berada di Sub DAS Lesti yang merupakan bagian dari DAS Brantas Hulu. Secara geografis Sub DAS Lesti berbentuk memanjang terletak diantara 80 02' 50" - 80 12' 10" Lintang Selatan dan 1120 42' 58" sampai 1120 56' 21" Bujur Timur. Sub DAS Lesti bagian Hilir berada di 9 kecamatan di Kabupaten Malang antara lain: Turen, 
Gedangan, Pagelaran, Wajak, Bantur, Bululawang, Sumbermanjingwetan, Gondanglegi, dan Pagak. Pada Sub DAS Lesti ini terdapat stasiun pemantauan berupa Automatic Water Level Record (AWLR) dan Automatic Rainfall Record (ARR) yang merupakan dalam pengelolaan Perum Jasa Tirta I.

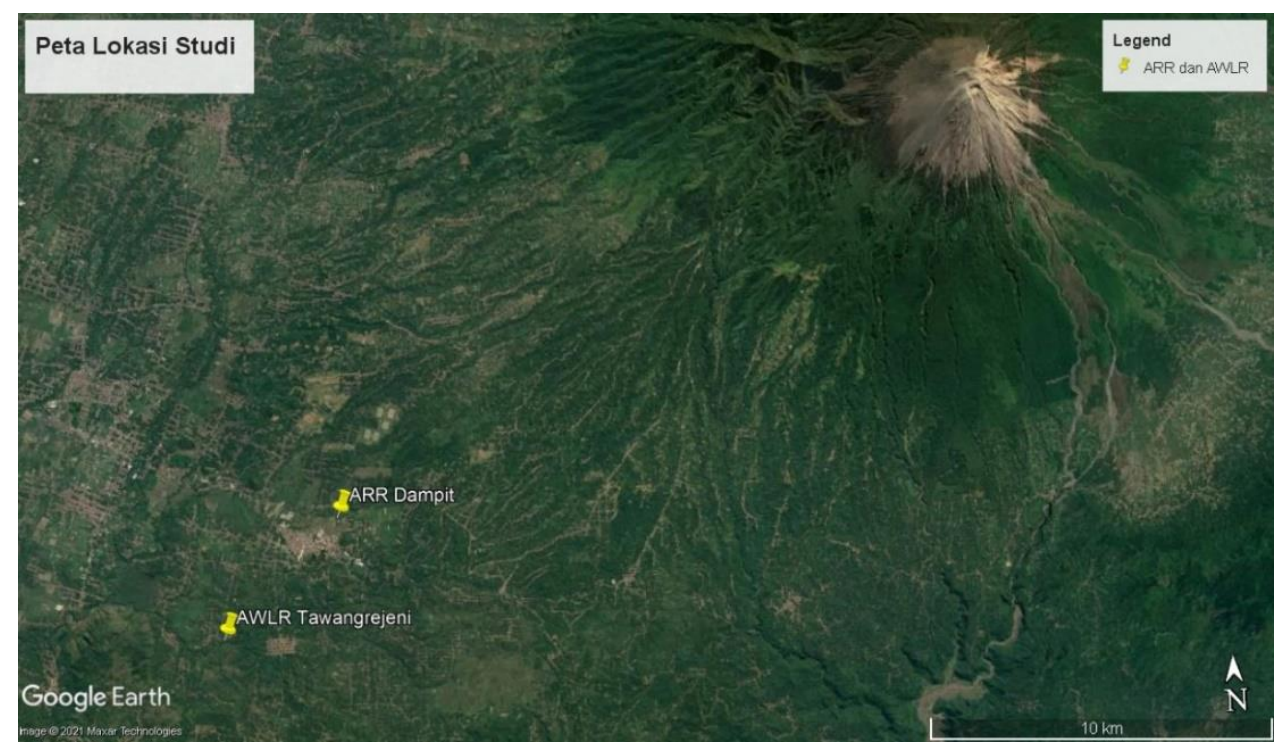

Gambar 1: Peta Lokasi Studi

Data yang digunakan untuk menunjang ketelitian penelitian ini adalah data sekunder. Data ini didapatkan dari berbagai instansi terkait seperti Perum Jasa Tirta I. Data yang digunakan adalah sebagai berikut;

- Pasangan rekaman data hujan jam - jaman dari alat Automatic Rainfall Recorder (ARR) dan data aliran dari alat Automatic Water Level Recorder (AWLR) selama 10 tahun.

- Data Peta Rupa Bumi dengan skala 1 : 25.000 atau 1 : 50.000 dan Peta Sub Daerah Aliran Sungai Lesti untuk analisa karakteristik Sub DAS Lesti dengan menggunakan Software pemetaan.

\subsection{Metode}

Sebelum penelitian, dilakukan pengumpulan data-data curah hujan (ARR), data debit (AWLR) dan data DEM. Setelah semua data terkumpul, dilakukan uji kualitas data untuk data debit dan data curah hujan yang terdiri dari uji konsistensi, uji persistensi, uji stasioner dan uji outlier. Data DEM diolah dengan menggunakan software pemetaan untuk mendapatkan data morfologi DAS Lesti. Setelah uji kualitas data dan morfologi sungai didapat, penelitian dilanjutkan dengan analisis hidrograf satuan observasi dengan metode Collins yang kemudian direkapitulasi. Selanjutnya dicari debit banjir rancangan dengan menggunakan HSS Nakayasu. Setelah didapat hasil dari HSO dan HSS dilakukan penyetaraan antara hujan serial dan hujan rancangan.

\subsection{Persamaan}

\subsubsection{Uji Konsistensi}

Data yang diperoleh dari perekam dan ARR mungkin tidak akurat. Ini dapat disebabkan oleh banyak alasan seperti pergerakan alat, kerusakan alat, alat terganggu, atau data yang 
tidak sah. Oleh karena itu, perlu dilakukan pengujian terhadap data curah hujan. Metode RAPS hanya dapat digunakan untuk satu stasiun [3]. Jika Q/n yang dihasilkan lebih kecil dari nilai kritis, maka data dinyatakan konsisten. Untuk pemeriksaan konsistensi, dapat menggunakan rumus berikut:

$$
\begin{array}{ll}
\mathrm{Sk} *=\sum_{i=1}^{n}(Y 1-Y) & \text { Pers. 1 } \\
\mathrm{Sk} * *=\frac{S k *}{D y} & \text { Pers. 2 } \\
\text { Dy2 }=\sum_{i=1}^{n} \frac{\left(Y 1-Y^{2}\right)}{n} & \text { Pers. 3 }
\end{array}
$$

\subsubsection{Uji Stasioner}

Uji stasioner bisa dipakai untuk menguji dari nilai kestabilan varian dan nilai rerata berdasarkan sebuah deret berkala misalnya pasangan data curah hujan dan data debitnya. Data yang dipakai, membutuhkan nilai varian dan rata-ratanya tidak mengalami perubahan yang sistematik sepanjang saat atau bisa dikatakan konstan[4].

$$
\begin{array}{ll}
\sigma=\left|\frac{N 1 * S d 1^{2}+N 2 * S d 2^{2}}{N 1+N 2-2}\right|^{0.5} & \text { Pers. } 4 \\
\mathrm{t}=\frac{|x 1-x 2|^{1 / 2}}{\sigma\left|\frac{1}{\mathrm{n} 1}+\frac{1}{\mathrm{n} 2}\right|} & \text { Pers. } 5 \\
\mathrm{f}=\frac{N 1 * S d 1^{2} *(N 2-1)}{N 2 * S d 2^{2} *(N 1-1)} & \text { Pers. } 6
\end{array}
$$

\subsubsection{Uji Outlier}

Outliers merupakan data-data yang menyimpang relatif jauh menurut trend-trend kelompoknya. Keberadaan outliers umumnya dianggap mengganggu pemilihan dari suatu jenis distribusi sampel data, sebagai akibatnya outliers ini perlu dihilangkan [5]. Persamaan yang dipakai untuk memutuskan nilai batas atas dan nilai dari batas bawah outliers adalah:

$$
\begin{array}{ll}
y_{H}=\bar{y}+K_{n} \cdot s_{y} & \text { Pers. } 7 \\
y_{L}=\bar{y}-K_{n} \cdot s_{y} & \text { Pers. } 8
\end{array}
$$

\subsubsection{Uji Persistensi}

Persistensi memiliki arti ketidak tergantungan berdasarkan setiap nilai pada deret berkala. Untuk melakukan uji persistensi wajib dilakukan dengan menghitung besarnya koefisien hubungan seri. Rumus yang dipakai adalah :

$$
\begin{array}{lc}
K S=1-\frac{6 \sum_{i-1}^{m}(d i)^{2}}{m^{3}-m} & \text { Pers. } 9 \\
t=K S\left[\frac{m-2}{1-K S^{2}}\right]^{\frac{1}{2}} & \text { Pers. } 10
\end{array}
$$

\subsubsection{Distribusi Gumbel}

Menurut Gumbel, perkara tertua merupakan berhubungan dengan nilai-nilai ekstrem yang tiba dari masalah banjir [6]. Tujuan teori statistik nilai ekstrim adalah untuk 
menganalisis output pengamatan nilai-nilai ekstrim tersebut untuk memperkirakan hasil dari nilai ekstrim berikutnya.

$$
x=\bar{x}+\frac{Y T-Y n}{S n} \sigma_{n} \quad \text { Pers. } 11
$$

\subsubsection{Distribusi Log Pearson}

Distribusi logaritmik-Pearson tipe III banyak digunakan dalam analisis hidrologi, terutama ketika menggunakan nilai ekstrim untuk menganalisis data maksimum (banjir) dan minimum (aliran minimum) [7].

$$
\log X=\overline{\log X}+G * S \quad \text { Pers. } 12
$$

\subsubsection{Uji Kesesuaian Distribusi Smirnov-Kolmogorof}

Uji Smirnov-Kolmogorof digunakan untuk menguji distribusi horizontal data. Pengujian ini dilakukan dengan cara membandingkan probabilitas setiap potongan data antara distribusi empiris dan distribusi teoritis.[8].

$$
\Delta \text { maks }=[\mathrm{Pe}-\mathrm{Pt}] \quad \text { Pers. } 13
$$

\subsubsection{Uji Kesesuaian Distribusi Chi-Square}

Uji Chi Square dilakukan untuk uji kesesuaian distribusi. Rumus Chi Square (X2) sebagai berikut [8].

$$
X_{\text {hitung }}^{2}=\sum_{i=1}^{k} \frac{(F e-F t)^{2}}{F t} \quad \text { Pers. } 14
$$

\subsubsection{HSO Metode Collins}

Hidrograf yang dihitung atau didapat menurut suatu banjir adalah hidrograf yang belum mewakili DAS tersebut. Sehingga perlu adanya suatu hidrograf satuan yang dihasilkan atau diturunkan berdasarkan berbagai banyak perkara banjir. Dalam proses merata-rata, hendaknya ordinat yang ada, tidak langsung dirata-rata karena akan memperoleh hasil hidrograf satuan yang lebih kecil dibandingkan nilai rata-rata debit puncak hidrograf satuan[9].

$$
\begin{array}{ll}
\mathrm{Ue}=(\mathrm{V} \times \mathrm{U} * *) /\left(3600 \times \sum \mathrm{U} * *\right) & \text { Pers. } 15 \\
\mathrm{U} * *=(\mathrm{U} 1+\mathrm{F} * \mathrm{x} \mathrm{U} *) /(1+\mathrm{F}) & \text { Pers. } 16 \\
\mathrm{U} *=\mathrm{dQ} / \text { Remaks } & \text { Pers. } 17
\end{array}
$$

\subsubsection{HSS Nakayasu}

Nakayasu dari Jepang mempelajari proses hidrograf satuan dari banyak sungai di Jepang. Ia membuat rumus hidrologi satuan sintetik berdasarkan penelitiannya sendiri, sebagai berikut: [9]:

$$
Q p=\frac{C A \cdot R o}{3,6\left(0,3 T p+T_{0,3}\right)} \quad \text { Pers. } 18
$$




\section{Hasil dan Pembahasan}

\subsection{Analisa Kualitas Data}

Data-data yang sudah diambil dari lapangan, harus diuji secara statistik. Tujuannya adalah mengetahui kualitas dari data tersebut, dikarenakan adanya kemungkinan gangguan atau masalah saat proses dalam pengambilan data[10].

Tabel 1: Uji Kualitas Data

\begin{tabular}{ccccccc}
\hline \multirow{2}{*}{ No } & \multirow{2}{*}{ Data } & \multirow{2}{*}{ Uji RAPS } & \multicolumn{2}{c}{ Uji Stasioner } & \multirow{2}{*}{ Uji Persistensi } & \multirow{2}{*}{ Uji Outlier } \\
\cline { 4 - 5 } & & & Uji F & Uji T & & \\
\hline 1 & Debit & Konsisten & Stabil & Stabil & Acak & Tidak Menyimpang \\
2 & Curah Hujan & Konsisten & Stabil & Stabil & Acak & Tidak Menyimpang \\
\hline
\end{tabular}

3.2 Analisis Daerah Aliran Sungai

Tabel 2: Karakteristik DAS Lesti

\begin{tabular}{ccc}
\hline No & Parameter Fisik & Hasil \\
\hline 1 & Luas DAS $\left(\mathrm{km}^{2}\right)$ & 378.85 \\
2 & Panjang Sungai $(\mathrm{km})$ & 37.1 \\
3 & Koefisien Pengaliran $(\mathrm{C})$ & 0.24 \\
\hline
\end{tabular}

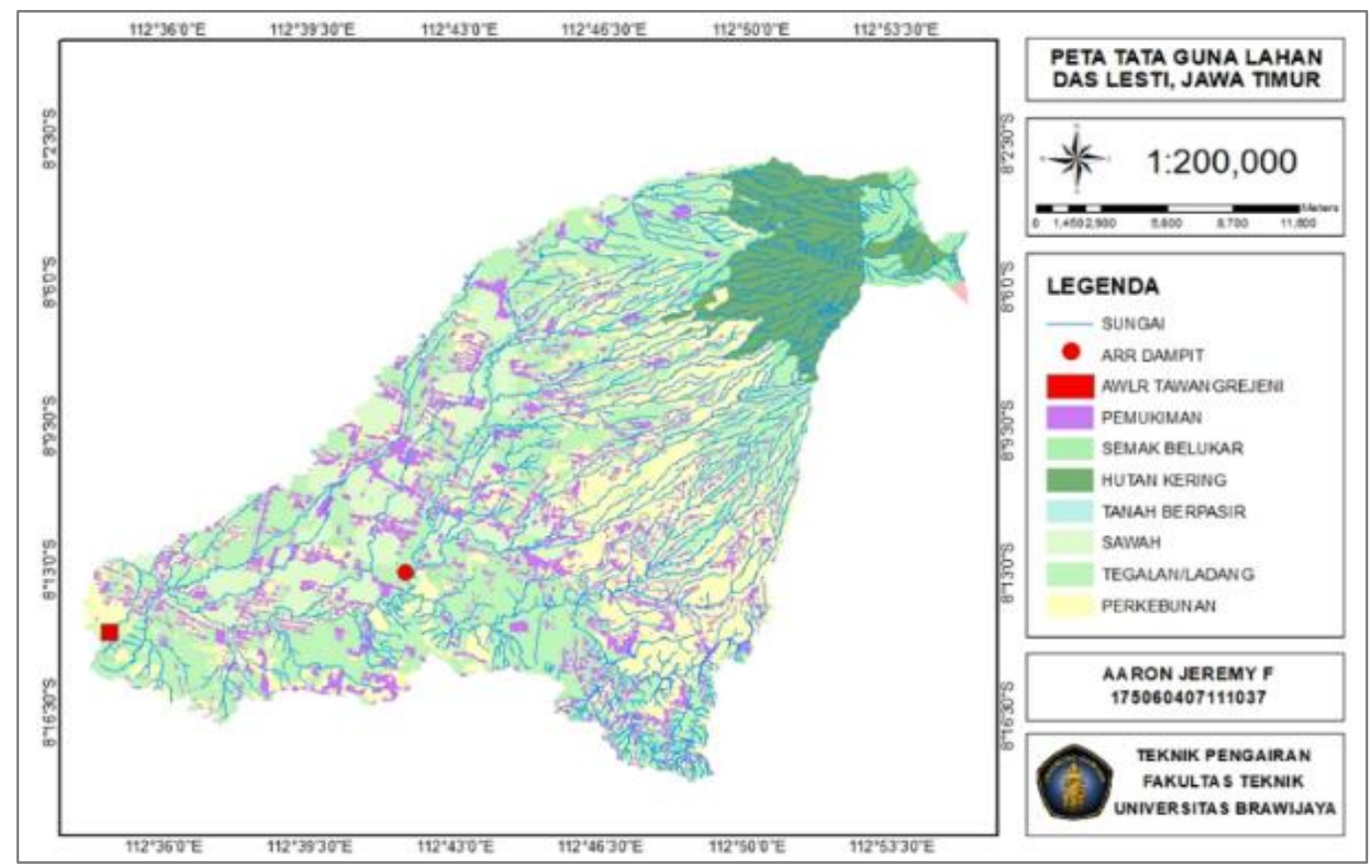

Gambar 2: Peta Tata Guna Lahan DAS Lesti

3.3 Analisa Hidrograf Satuan Pengamatan Metode Collins

Dalam analisis ini, harus memilih hidrograf yang terpisah dan mempunyai satu puncak. Syarat tersebut diperlukan untuk mempermudah hasil perhitungan. Dalam hal ini, 
metode Collins dapat digunakan. Metode Collins adalah cara untuk mencari nilai hidrograf satuan pengamatan dengan data hujan periode kompleks. Hidrograf satuan yang dihitung dari satu kasus banjir masih belum merupakan hidrograf yang mewakili DAS yang bersangkutan. Karenanya dibutuhkan hidrograf yang diturunkan dari banyak kasus banjir, lalu dirata-rata. Namun jumlah pasti berapa jumlah kasus banjir yang diperlukan tidak diketahui secara pasti [11]. Tahapan yang perlu dilakukan adalah:

a. Menghitung waktu puncak rata-rata dan debit puncak rata-rata.

b. Menghitung hidrografsatuan pengamatan tak berdimensi (t/TP dan $Q / Q P)$ untuk masing-masing kasus.

c. Menghitung hidrograf satuan pengamatan (HSO) rata-rata tak berdimensi.

d. Menghitung hidrograf satuan pengamatan (HSO) rata-rata.

Tabel 3: Rerata HSP Metode Collins DAS Lesti

\begin{tabular}{|c|c|c|c|c|}
\hline No & $\mathrm{t} / \mathrm{Tp}$ & $\mathrm{Q} / \mathrm{Qp}$ & $\mathrm{T}$ & $\mathrm{Q}$ \\
\hline 1 & 0.00 & 0.00 & 0.00 & 0.000 \\
\hline 2 & 0.07 & -0.01 & 0.35 & -0.096 \\
\hline 3 & 0.13 & -0.01 & 0.69 & -0.152 \\
\hline 4 & 0.20 & -0.02 & 1.04 & -0.206 \\
\hline 5 & 0.27 & -0.02 & 1.39 & -0.261 \\
\hline 6 & 0.17 & -0.01 & 0.87 & -0.093 \\
\hline 7 & 0.10 & 0.01 & 0.52 & 0.148 \\
\hline 8 & 0.13 & 0.03 & 0.69 & 0.333 \\
\hline 9 & 0.17 & 0.04 & 0.87 & 0.487 \\
\hline 10 & 0.20 & 0.04 & 1.04 & 0.548 \\
\hline 11 & 0.23 & 0.07 & 1.21 & 0.889 \\
\hline 12 & 0.25 & 0.07 & 1.29 & 0.955 \\
\hline 13 & 0.32 & 0.09 & 1.66 & 1.121 \\
\hline 14 & 0.44 & 0.28 & 2.27 & 3.592 \\
\hline 15 & 0.72 & 0.59 & 3.74 & 7.644 \\
\hline 16 & 1.00 & 1.00 & 5.20 & 12.992 \\
\hline 17 & 1.28 & 0.81 & 6.66 & 10.578 \\
\hline 18 & 1.56 & 0.58 & 8.13 & 7.538 \\
\hline 19 & 1.85 & 0.44 & 9.59 & 5.741 \\
\hline 20 & 2.13 & 0.33 & 11.06 & 4.344 \\
\hline 21 & 2.41 & 0.26 & 12.52 & 3.324 \\
\hline 22 & 2.69 & 0.20 & 13.99 & 2.565 \\
\hline 23 & 2.97 & 0.15 & 15.45 & 1.975 \\
\hline 24 & 3.25 & 0.10 & 16.92 & 1.324 \\
\hline 25 & 3.54 & 0.08 & 18.38 & 1.035 \\
\hline 26 & 3.82 & 0.06 & 19.85 & 0.779 \\
\hline 27 & 4.10 & 0.05 & 21.31 & 0.596 \\
\hline 28 & 4.38 & 0.03 & 22.78 & 0.399 \\
\hline 29 & 5.55 & 0.04 & 28.86 & 0.467 \\
\hline 30 & 6.25 & 0.04 & 32.50 & 0.464 \\
\hline 31 & 6.63 & 0.03 & 34.45 & 0.372 \\
\hline 32 & 7.00 & 0.02 & 36.40 & 0.233 \\
\hline 33 & 6.95 & 0.01 & 36.14 & 0.193 \\
\hline 34 & 7.30 & 0.01 & 37.96 & 0.097 \\
\hline 35 & 8.39 & 0.00 & 43.62 & 0.000 \\
\hline
\end{tabular}




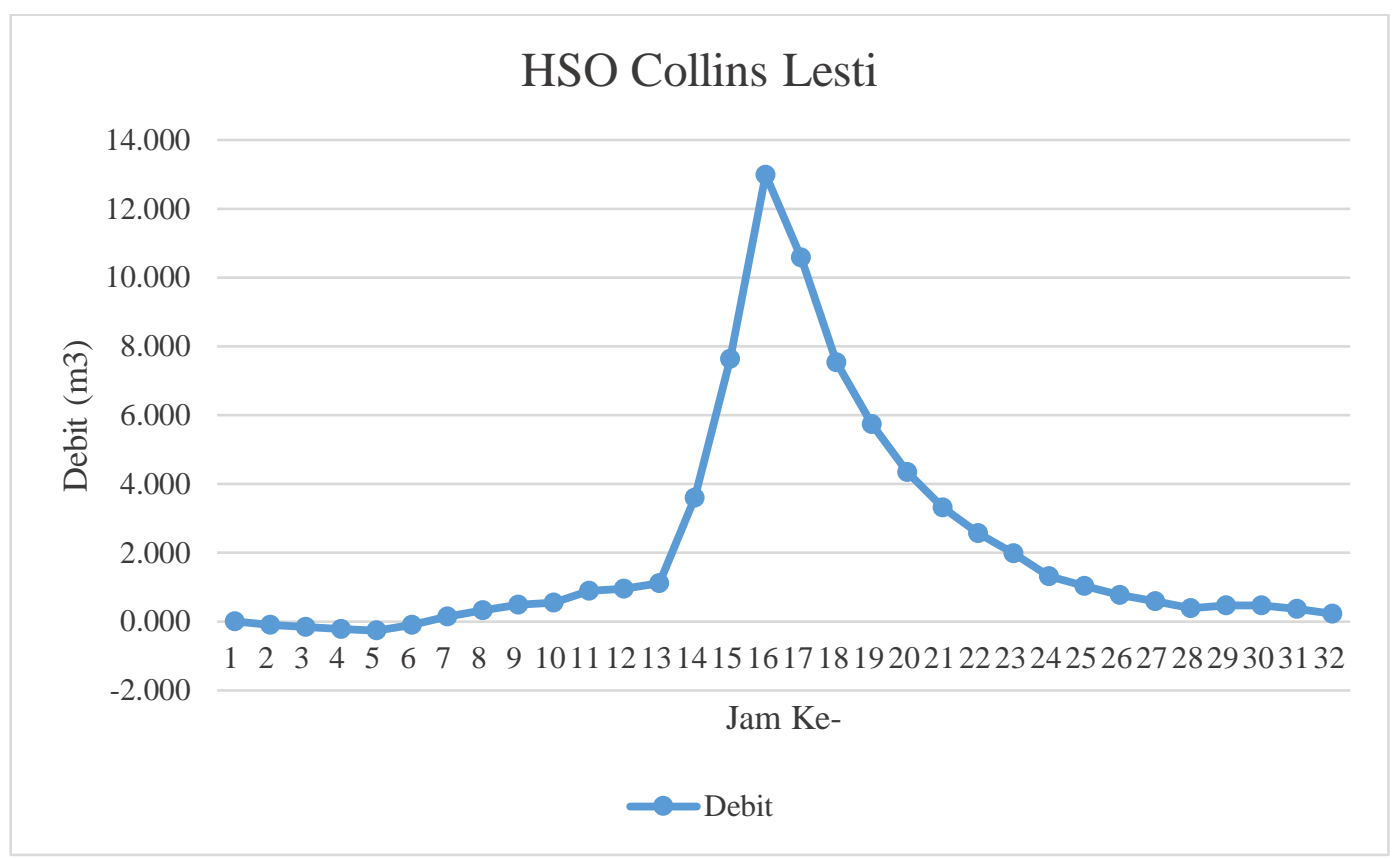

Gambar 3: Grafik HSP Rerata Metode Collins DAS Lesti

\subsection{Analisa Curah Hujan Rancangan}

Tujuan dari statistik harga ekstrim adalah untuk menganalisis hasil pengamatan harga ekstrim tersebut dan menghitung harga ekstrim berikutnya [12].

Tabel 4: Hasil Distribusi Frekuensi Metode Gumbel

\begin{tabular}{ccccc}
\hline $\operatorname{Tr}$ & $\mathrm{Y}_{\mathrm{T}}$ & $\mathrm{K}$ & $\mathrm{Sd} . \mathrm{K}$ & Hujan rancangan \\
\hline 2 & 0.367 & -0.14 & -3.03 & 87.37 \\
5 & 1.500 & 1.06 & 23.65 & 114.05 \\
10 & 2.250 & 1.85 & 41.31 & 131.71 \\
25 & 3.199 & 2.85 & 63.63 & 154.03 \\
50 & 3.902 & 3.59 & 80.19 & 170.59 \\
100 & 4.600 & 4.32 & 96.62 & 187.02 \\
200 & 5.296 & 5.06 & 113.00 & 203.40 \\
1000 & 6.907 & 6.75 & 150.93 & 241.33 \\
\hline
\end{tabular}

\subsection{Analisa Curah Hujan Rancangan Metode Log Pearson III}

Selain distribusi Gumbel, metode Log Pearson III juga dapat digunakan untuk mencari hujan rencana. Distribusi Log-Pearson Tipe III banyak digunakan dalam analisis hidrologi, terutama untuk analisis data maksimum (banjir) dan minimum (aliran minimum) dengan nilai ekstrim. Curah hujan rancangan metode Log Pearson Tipe III dapat digunakan pada semua sebaran data tanpa harus memenuhi syarat koefisien kepencengan (skewness) dan koefisien kepuncakan (kurtosis) [13]. 
Tabel 5: Hasil Distribusi Frekuensi Metode Log Pearson III

\begin{tabular}{cccccc}
\hline $\operatorname{Tr}$ & $\operatorname{Pr}(\%)$ & $\mathrm{K}$ & K. SD & $\begin{array}{c}\text { Log Qrancangan } \\
\left(\mathrm{m}^{3} / \mathrm{s}\right)\end{array}$ & $\begin{array}{c}\text { Hujan rancangan } \\
\left(\mathrm{m}^{3} / \mathrm{s}\right)\end{array}$ \\
\hline 2 & 50 & 0.11 & 0.01 & 1.96 & 90.39 \\
5 & 20 & 0.86 & 0.10 & 2.04 & 110.35 \\
10 & 10 & 1.19 & 0.14 & 2.08 & 120.52 \\
25 & 4 & 1.49 & 0.17 & 2.12 & 130.91 \\
50 & 2 & 1.64 & 0.19 & 2.13 & 136.34 \\
100 & 1 & 1.81 & 0.21 & 2.15 & 142.55 \\
200 & 0,5 & 1.95 & 0.23 & 2.17 & 147.85 \\
1000 & 0,1 & 2.17 & 0.25 & 2.20 & 156.85 \\
\hline
\end{tabular}

3.6 Analisa Uji Kesesuaian Distribusi

Tabel 6: Rekapitulasi Hasil Uji Chi Square dan Smirnov-Kolmogorof

\begin{tabular}{ccccccc}
\hline \multicolumn{7}{c}{ Uji Chi Square } \\
\hline No & Distribusi & KR & D kritis & $X^{2}$ hitung & Keterangan \\
\hline 1 & Gumbel & 0.05 & 1.200 & 3.841 & $X^{2}{ }_{\text {hitung }}>$ D cr & Hipotesa Diterima \\
2 & Log Pearson & 0.05 & 3.021 & 3.841 & $X^{2}{ }_{\text {hitung }}>$ D cr & Hipotesa Diterima \\
\hline \multicolumn{7}{c}{ Uji Smirnov Kolmogorof } \\
\hline \multirow{2}{*}{ No } & \multirow{2}{*}{ Distribusi } & \multirow{2}{*}{ KR } & D kritis & D maks & Keterangan \\
& Gumbel & 0.05 & 0.175 & 0.409 & D maks < D cr' & Hipotesa Diterima \\
2 & Log Pearson & 0.05 & 0.180 & 0.409 & D maks $<$ D cr' & Hipotesa Diterima \\
\hline
\end{tabular}

Berdasarkan uji kesesuaian distribusi yang telah dilakukan, didapatkan dari tabel rekapitulasi bahwa nilai distribusi Gumbel adalah yang sesuai karena memilki Dmaks (simpangan) yang relatif lebih kecil daripada distribusi Log Pearson III.

3.6 Distribusi Hujan Jam-Jaman Metode Mononobe

Rumus Mononobe yang merupakan variasi dari rumus Talbot, Sherman, dan Ishiguro yang merupakan rumus intensitas curah hujan untuk curah hujan jangka pendek [14].

Tabel 7: Perhitungan Distribusi Jam-Jaman Metode Mononobe

\begin{tabular}{|c|c|c|c|c|c|c|c|c|c|c|}
\hline \multirow{2}{*}{ No. } & \multirow{2}{*}{ Jam ke- } & \multirow{2}{*}{ Rasio } & \multicolumn{8}{|c|}{ Hujan jam-jaman } \\
\hline & & & 2 & 5 & 10 & 25 & 50 & 100 & 200 & 1000 \\
\hline 1 & 1.00 & 055 & 11.5 & 15.06 & 17.39 & 20.34 & 22.53 & 24.70 & 26.8 & 31.87 \\
\hline 2 & & & 2. & 3.9 & 4.52 & & 5.8 & 2 & 8 & 8.28 \\
\hline 3 & & & 2. & 2.7 & 3.17 & 3 & 4.10 & .50 & 4.8 & 5.81 \\
\hline 4 & 4 & & 1.67 & 2. & 2. & 2. & 3.2 & 3.58 & 3.89 & 4.62 \\
\hline 5 & & & 1.4 & 1.8 & 2. & 2.49 & 2.7 & 22 & 3.29 & 3.90 \\
\hline 6 & 6.00 & 0.0 & 1.23 & 1.61 & 1.86 & 2.18 & 2.41 & 2.64 & 2.87 & 3.41 \\
\hline \multicolumn{3}{|c|}{ Jumlah } & 20.9 & 27.37 & 31.61 & 36.96 & 40.94 & 44.88 & 48.81 & 57.91 \\
\hline \multicolumn{3}{|c|}{ Hujan Rancangan } & 87 & & & 154.0 & 170.5 & 187.0 & 203.4 & 241.3 \\
\hline \multicolumn{3}{|c|}{ Koefisien Pengaliran } & 0.24 & 0.240 & 0.240 & 0.24 & 0.240 & 0.240 & 0.24 & 0.24 \\
\hline \multicolumn{3}{|c|}{ Hujan Efektif } & 20.9 & 27.37 & 31.61 & 36.96 & 40.9 & 44.88 & 48.8 & 57.91 \\
\hline
\end{tabular}




\subsection{Hidrograf Satuan Sintetis (HSS) Nakayasu}

Hidrograf Satuan Sintetis adalah tinggi muka air limpasan langsung yang terdapat di bagian hilir DAS yang disebabkan oleh satuan curah hujan efektif dengan intensitas tertentu. Perhitungan HSS didasarkan pada karakteristik fisik DAS yang diawali dengan perhitungan hujan rancangan berbagai kala ulang. Distribusi frekuensi yang dipilih adalah Log Pearson III karena dianggap relatif fleksibel.Dari hasil HSS Nakayasu akan didapatkan hasil debit desain DAS Lesti dan dengan kala ulang tertentu. Hidrograf dapat digambarkan sebagai penyajian grafis antara salah satu unsur aliran dengan waktu. Hidrograf ini menunjukkan tanggapan menyeluruh DAS terhadap masukan tertentu. Sesuai dengan sifat dan perilaku DAS yang bersangkutan, hidrograf aliran selalu berubah sesuai dengan besaran dan waktu terjadinya masukan[15]. Adapun Langkah-langkah perhitungan yang diperlukan untuk menghitung HSS nakayasu, yaitu:

a. Menghitung parameter-parameter yang diperlukan.

b. Menghitung nilai dari koordinat kurva turun dan naik hidrograf.

c. Menghitung hidrograf dengan kala ulang tertentu.

Tabel 8: Ordinat Hidrograf Satuan Sintetik Nakayasu

\begin{tabular}{ccc}
\hline $\mathrm{T}(\mathrm{jam})$ & $\mathrm{Q}\left(\mathrm{m}^{3} / \mathrm{dt} / \mathrm{mm}\right)$ & Keterangan \\
\hline 0 & 0.000 & \\
1 & 0.288 & Qn \\
2 & 1.521 & \\
3 & 4.025 & Qp \\
4 & 8.028 & \\
\hline 4.723 & 11.963 & \\
\hline 5 & 11.435 & Qt1 \\
6 & 9.713 & \\
7 & 8.251 & \\
8 & 7.009 & \\
9 & 5.954 & \\
10 & 5.058 & \\
11 & 4.046 & \\
12 & 3.629 & \\
13 & 3.255 & \\
14 & 2.920 & \\
15 & 2.619 & \\
16 & 2.349 & \\
17 & 2.107 & \\
18 & 1.890 & \\
19 & 1.695 & \\
20 & 1.520 & \\
21 & 1.364 & \\
22 & 1.185 & \\
23 & 1.092 & \\
24 & 1.006 & \\
& & \\
\hline
\end{tabular}


Tabel 9: Rekapitulasi Perhitungan Hidrograf Debit Banjir Rancangan Metode Nakayasu

\begin{tabular}{|c|c|c|c|c|c|c|c|c|}
\hline \multirow{2}{*}{$\mathrm{T}$} & \multicolumn{8}{|c|}{ Debit Banjir Rancangan $\left(\mathrm{m}^{3} / \mathrm{dt}\right)$} \\
\hline & 2 th & 5 th & 10 th & 25 th & 50 th & 100 th & 200 th & 1000 th \\
\hline 0 & 16.616 & 16.616 & 16.616 & 16.616 & 16.616 & 16.616 & 16.616 & 16.616 \\
\hline 1 & 19.942 & 20.957 & 21.630 & 22.479 & 23.109 & 23.735 & 24.358 & 25.802 \\
\hline 2 & 35.033 & 40.656 & 44.380 & 49.084 & 52.574 & 56.038 & 59.489 & 67.485 \\
\hline 3 & 68.231 & 83.991 & 94.427 & 107.61 & 117.39 & 127.10 & 136.77 & 159.18 \\
\hline 4 & 125.01 & 158.11 & 180.02 & 207.71 & 228.25 & 248.64 & 268.96 & 316.01 \\
\hline 5 & 184.07 & 235.20 & 269.05 & 311.83 & 343.56 & 375.06 & 406.44 & 479.14 \\
\hline 6 & 189.14 & 241.82 & 276.70 & 320.77 & 353.46 & 385.91 & 418.25 & 493.15 \\
\hline 7 & 186.04 & 237.78 & 272.03 & 315.31 & 347.42 & 379.29 & 411.04 & 484.60 \\
\hline 8 & 178.17 & 227.50 & 260.16 & 301.42 & 332.04 & 362.43 & 392.71 & 462.84 \\
\hline 9 & 166.07 & 211.71 & 241.93 & 280.11 & 308.43 & 336.54 & 364.56 & 429.44 \\
\hline 10 & 149.28 & 189.79 & 216.62 & 250.50 & 275.64 & 300.60 & 325.46 & 383.06 \\
\hline 11 & 126.42 & 159.95 & 182.16 & 210.21 & 231.02 & 251.67 & 272.25 & 319.93 \\
\hline 12 & 111.36 & 140.29 & 159.45 & 183.65 & 201.60 & 219.43 & 237.19 & 278.32 \\
\hline 13 & 99.141 & 124.33 & 141.02 & 162.10 & 177.74 & 193.26 & 208.73 & 244.56 \\
\hline 14 & 89.004 & 111.10 & 125.74 & 144.23 & 157.95 & 171.56 & 185.13 & 216.56 \\
\hline 15 & 80.501 & 100.00 & 112.92 & 129.24 & 141.34 & 153.36 & 165.33 & 193.07 \\
\hline 16 & 73.311 & 90.623 & 102.08 & 116.56 & 127.31 & 137.97 & 148.60 & 173.21 \\
\hline 17 & 67.469 & 82.996 & 93.278 & 106.26 & 115.90 & 125.46 & 134.99 & 157.07 \\
\hline 18 & 62.228 & 76.155 & 85.378 & 97.028 & 105.67 & 114.25 & 122.80 & 142.60 \\
\hline 19 & 57.528 & 70.020 & 78.291 & 88.741 & 96.494 & 104.18 & 111.85 & 129.61 \\
\hline 20 & 53.312 & 64.516 & 71.936 & 81.308 & 88.262 & 95.164 & 102.04 & 117.97 \\
\hline 21 & 49.530 & 59.580 & 66.235 & 74.642 & 80.879 & 87.070 & 93.238 & 107.52 \\
\hline 22 & 45.695 & 54.574 & 60.453 & 67.880 & 73.391 & 78.861 & 84.311 & 96.935 \\
\hline 23 & 42.921 & 50.953 & 56.271 & 62.990 & 67.975 & 72.923 & 77.853 & 89.273 \\
\hline 24 & 40.529 & 47.830 & 52.665 & 58.773 & 63.304 & 67.802 & 72.284 & 82.666 \\
\hline Q & 189.1 & 241.8 & 276.70 & 320.77 & 353.46 & 385.91 & 418.25 & 493.15 \\
\hline
\end{tabular}

3.8 Perbandingan antara HSS Nakayasu dengan Collins

Perbandingan antara hidrograf metode Collins dan Nakayasu adalah terdapat pada selisih nilai Qp atau debit puncak. Nilai puncak pada hidrograf Collins terdapat pada jam ke 5.2 dan Nakayasu terdapat pada jam-ke 4.7, dengan nilai Qp untuk metode Collins adalah sebesar $12.992 \mathrm{~m} 3 / \mathrm{dt} / \mathrm{mm}$ sedangakan untuk metode Nakayasu adalah sebesar $11.962 \mathrm{~m} 3 / \mathrm{dt} / \mathrm{mm}$. Dari hasil yang didapat, dapat dilihat bahwa terdapat penyimpangan yang terjadi antara nilai Qp dan Tp metode Collins dan Nakayasu yang disebabkan oleh parameter alfa pada HSS Nakayasu yang belum terkalibrasi.Untuk hasil ordinat yang didapatkan, dapat dilihat pada grafik dibawah ini:

Tabel 10: Nilai KR dari Qp dan Tp HSS Nakayasu

\begin{tabular}{cccccc}
\hline $\begin{array}{c}\text { Tp Nakayasu } \\
\text { (jam) }\end{array}$ & $\begin{array}{c}\text { Tp Collins } \\
\text { (jam) }\end{array}$ & $\begin{array}{c}\text { KR } \\
(\%)\end{array}$ & $\begin{array}{c}\text { Qp } \\
\text { Nakayasu }\end{array}$ & $\begin{array}{c}\text { Qp } \\
\text { Collins }\end{array}$ & $\begin{array}{c}\text { KR } \\
(\%)\end{array}$ \\
\hline 4.723 & 5.2 & 9.173 & 11.693 & 12.992 & 9.999 \\
\hline
\end{tabular}




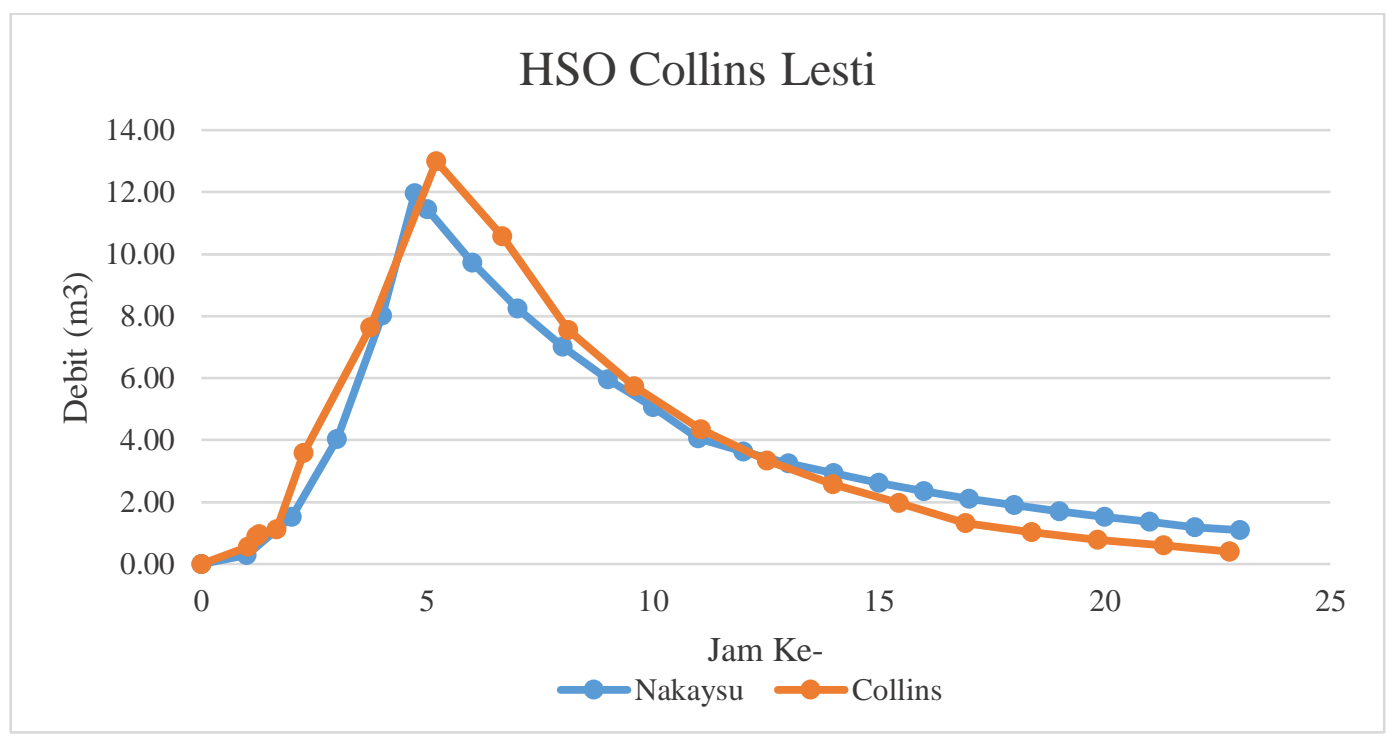

Gambar 4: Grafik Perbandingan HSS Nakayasu dan Metode Collins

Dari grafik yang terlihat diatas, nilai Qp dan Tp antara Collins dan Nakayasu memiliki hasil penyimpangan yang besar. Dapat dilihat bahwa terdapat penyimpangan yang terjadi antara nilai Qp dan Tp metode Collins dan Nakayasu yang disebabkan oleh parameter alfa pada HSS Nakayasu yang belum terkalibrasi.

3.9 Perbandingan Curah Hujan Serial dan Curah Hujan Rancangan

Hujan rancangan yang sudah dihitung dengan menggunakan distribusi Gumbel, akan disandingkan dengan debit rancangan HSS Nakayasu dan hujan serial.

Tabel 11: Perbandingan Curah Hujan Serial dan Curah Hujan Rancangan

\begin{tabular}{|c|c|c|c|c|c|c|c|c|}
\hline \multicolumn{3}{|c|}{ HSS Nakayasu } & \multicolumn{5}{|c|}{ HSO Collins } & \multirow[b]{2}{*}{$\begin{array}{l}\text { Keadaan Curah } \\
\text { Hujan }\end{array}$} \\
\hline $\operatorname{Tr}$ & $\mathrm{R}$ & $\begin{array}{c}\mathrm{Q} \\
\left(\mathrm{m}^{3} / \mathrm{dt}\right)\end{array}$ & $\begin{array}{c}\text { Tanggal } \\
\text { KB }\end{array}$ & $\mathrm{T}$ & $\begin{array}{c}\text { Q AWLR } \\
\left(\mathrm{m}^{3} / \mathrm{dt}\right)\end{array}$ & $\begin{array}{c}\text { R ARR } \\
(\mathrm{mm})\end{array}$ & $\mathrm{CH}_{\text {maks }}$ & \\
\hline \multirow{6}{*}{2} & \multirow{6}{*}{87.4} & \multirow{6}{*}{189.14} & & 1 & 46.44 & 24 & \multirow{6}{*}{58} & Hujan Sangat Lebat \\
\hline & & & & 2 & 110.09 & 9 & & Hujan Normal \\
\hline & & & 5 April & 3 & 187.29 & 14 & & Hujan Normal \\
\hline & & & 2015 & 4 & 180.71 & 6 & & Hujan Normal \\
\hline & & & & 5 & 136.06 & 4 & & Hujan Ringan \\
\hline & & & & 6 & 109.24 & 1 & & Hujan Ringan \\
\hline
\end{tabular}

Pada Tabel 11 dapat dilihat bahwa pada debit banjir dengan kala ulang 2 tahun dengan debit banjir rancangan $189.143 \mathrm{~m}^{3} / \mathrm{dt}$, memiliki nilai yang mendekati debit eksisting, yaitu sebesar $187,29 \mathrm{~m}^{3} / \mathrm{dt}$ pada tanggal 5 April 2015. Debit banjir tersebut terjadi saat adanya hujan normal pada jam tersebut, namun debit banjir sebesar 187,29 $\mathrm{m}^{3} / \mathrm{dt}$ terjadi karena akumulasi hujan sangat lebat dan hujan normal pada jam sebelumnya, yaitu hujan dengan tinggi $24 \mathrm{~mm}$ dan $9 \mathrm{~mm}$.

\section{Kesimpulan}

Berdasarkan analisis didapatkan, curah hujan serial dengan tinggi sebesar $58 \mathrm{~mm}$ akan setara dengan curah hujan rancangan sebesar $87,37 \mathrm{~mm}$ dengan kala ulang sebesar 2 tahun. 
Debit puncak dan waktu puncak antara Collins dan Nakayasu memiliki hasil penyimpangan dengan kesalahan relatif untuk waktu puncak sebesar $9,173 \%$, sedangkan untuk debit puncak sebesar 9,999\%.

Debit AWLR sebesar 187,29 m3/dt pada tanggal 5 April 2015 akan setara dengan debit banjir rancangan dengan kala ulang 2 tahun sebesar $189.143 \mathrm{~m} 3 / \mathrm{dt}$. Dari hasil rata-rata 10 kejadian banjir didapatkan bahwa rata-rata debit AWLR memiliki kesetaraan dengan debit banjir rancangan dengan kala ulang kurang dari 2 tahun.

\section{Daftar Pustaka}

[1] I. K. Sari, L. M. Limantara, and D. Priyantoro, "Analisa Ketersediaan dan Kebutuhan Air pada DAS Sampean,” J. Tek. Pengair., vol. 2, no. 1, pp. 29-41, 2012, [Online]. Available: www.Bapenas.go.id.

[2] M. Arsyad, "Modul Perhitungan Hidrologi Pelatihan Perencanaan Bendungan Tingkat Dasar 2017,” 2017.

[3] S. Harto, "Hidrologi," Nafiri Offset. Yogyakarta, 2000.

[4] I. L. M. Limantara, Rekayasa Hidrologi: Edisi Revisi. Penerbit Andi, 2018.

[5] C. V. Te, D. R. Maidment, and L. W. Mays, "Applied hydrology," Water Resour. Handb., 1988.

[6] E. J. Gumbel, "The return period of flood flows," Ann. Math. Stat., vol. 12, no. 2, pp. 163-190, 1941.

[7] C. D. Soemarto, "Hidrologi Teknik Jilid 2,” Jakarta: Erlangga, 1999.

[8] S. Harto, “Analisis hidrologi,” Gramedia Pustaka Utama, Jakarta, 1993.

[9] L. M. Limantara, "Hidrologi Praktis,” Bandung: Lubuk Agung, 2010.

[10] M. D. P. Gupta, R. Haribowo, and T. B. Prayogo, "Studi Penentuan Status Mutu Air Menggunakan Metode Indeks Pencemaran Dan WQI Di Tukad Badung, Denpasar," J. Tek. Pengair. J. Water Resour. Eng., vol. 11, no. 2, pp. 83-93, 2020.

[11] A. Priombodo, L. M. Limantara, and E. Suhartanto, "Kajian kalibrasi hidrograf representatif di das samiran kabupaten pamekasan," J. Tek. Pengair., vol. 3, no. 2, pp. 195-203, 2012.

[12] C. D. Soemarto, "Hidrologi Teknik Edisi 1," Surabaya Penerbit Usaha Nas., 1986.

[13] D. E. Guntoro, D. Harisuseno, and E. N. Cahya, "Pengelolaan Drainase Secara Terpadu Untuk Pengendalian Genangan Di Kawasan Sidokare Kabupaten Sidoarjo," J. Tenik Pengair., vol. 008, no. 01, pp. 60-71, 2017, doi: 10.21776/ub.jtp.2017.008.01.06.

[14] D. Harisuseno, S. Wahyuni, and Y. Dwirani, "Penentuan Formulasi Empiris Yang Sesuai Untuk Mengestimasi Kurva Intensitas Durasi Frekuensi," J. Tek. Pengair., vol. 11 , no. 1 , pp. 47-60, 2020.

[15] H. Siswoyo, "Pengembangan Model Hidrograf Satuan Sintetis Snyder untuk Daerah Aliran Sungai di Jawa Timur," J. Pengair., vol. 2, pp. 42-54, 2011, [Online]. Available: http://jurnalpengairan.ub.ac.id/index.php/jtp/article/view/119. 